\title{
Peer-assisted learning: a medical student perspective
}

\author{
Mohammad Amre Fallaha \\ Aalia Pagarkar \\ Nicholas Lucas \\ Faculty of Medicine, Imperial College \\ London, London, UK
}

This article was published in the following Dove Press journal: Advances in Medical Education and Practice

\section{Dear editor}

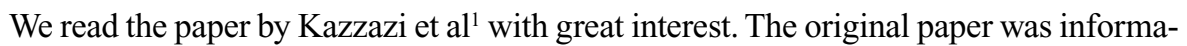
tive, and as penultimate year medical students at Imperial College, we want to share our unique perspective regarding student learning and the benefits of peer-assisted learning (PAL). We find that many subjects, including embryology as outlined in the paper, ${ }^{1}$ are complex and typically taught through lecture-based formats. While this may be understandable to readers of respective specialties, students may find certain concepts abstract and not easily grasped through lectures alone. Some medical schools have implemented practical model construction classes to facilitate embryology learning and have reported benefits for the students, ${ }^{2}$ whereas others have introduced student-led summary courses. ${ }^{1}$

Our learning experience at Imperial involves didactic lecture-based formats, which are often supplemented with short, intensive, summary tutorials run by senior students, much like those described in the study under consideration. One such example is MedEd, a medical education society, which provides tutorials for both theoretical and practical aspects of medicine.

As medical students, one topic that we strongly feel the study could have explored in detail are the benefits of PAL, for both students and tutors. Peer-to-peer teaching underpins modern medicine and is indeed a requirement as set out by the General Medical Council's “Tomorrow's Doctors" document. ${ }^{3}$

From our experience, students are arguably more in touch with the precise learning requirements of their peers. Senior students are also more likely to advise on useful revision strategies that are relatable to their student peers, as compared to lecturers. Finally, tutees may feel more comfortable communicating their worries in the relaxed environment PAL creates, and tutors may be able to explain content at an appropriate, understandable level for the tutees. ${ }^{4}$

PAL has many benefits for tutors too. From personal experience, and from previous studies, it has been demonstrated that teaching a topic creates intrinsic motivation to learn the material more thoroughly. There are also added developmental benefits such as boosting self-confidence, and taking on teaching roles may confer benefits in future job applications. ${ }^{4}$

The benefits of PAL are not just limited to students but extend to teaching institutions too. Teaching institutions are often limited by the availability of their teaching staff, many of whom may struggle to balance teaching with patient care. As such, senior
Correspondence: Mohammad Amre Fallaha

Faculty of Medicine, Imperial College London, South Kensington SW7 2AZ, London, UK

Tel +447982724970

Emailmafl3@imperial.ac.uk 
students are often in a greater position to teach, being less constrained by the professional workload and time limitations.

We believe that embracing PAL yields many benefits, with possible tutorial content not limited to the field of embryology. However, it is important to note that to teach, one must understand the theory of teaching, rather than just the concepts to be taught. At our institution, we are provided with a teaching skills course that outlines the fundamental principles of effective teaching. Moreover, tutorials should not substitute detailed lectures, but rather, act as supplements. Utilizing senior students as tutors also consolidates their knowledge and prepares them for future life where educating both their peers and patients is necessary.

\section{Disclosure}

The authors report no conflicts of interest in this communication.

\section{References}

1. Kazzaza F, Bartlett J. Condensing embryology teaching for medical students: can it be taught in 2 hours? Adv Med Educ Pract. 2017;8:797-806.

2. Aversi-Ferreira TA, Aversi-Ferreira RAGMF, Nascimento GN, et al. Teaching embryology using models construction in practical classes. Int J Morphol. 2012;30(1):188-195.

3. General Medical Council. Tomorrow's Doctors. [Brochure]; 2009. Available from: https://www.gmc-uk.org/Tomorrow_s_Doctors_1214. pdf_48905759.pdf. Accessed December 17, 2017.

4. Hermann-Werner A, Gramer R, Erschens R, et al. Peer-assisted learning (PAL) in undergraduate medical education: an overview. Adv Med Educ Pract. 2017;121:74-81. 


\section{Authors' reply}

Fawz Kazzazi

Jonathan Bartlett

School of Clinical Medicine, University of Cambridge,

Cambridge, UK

Correspondence: Fawz Kazzazi

School of Clinical Medicine, University of Cambridge, 37 Grange Road,

Leckhampton House, Cambridge CB2 IRH, UK

Tel +44775422005

Email fk276@cam.ac.uk

\section{Dear editor}

It was interesting to read Fallaha et al's personal reflection on embryology teaching. It expanded many of the points that we had considered when designing the course, particularly surrounding the benefits of peer-assisted learning on the tutee. ${ }^{1}$ Our course was not a "summary" by any extent and was comprehensive and covered the full embryology curriculum in an unorthodox didactic style in under 2 hours. ${ }^{1,2}$

We agree with the authors on the multiple benefits of senior student help. It also has wider benefits regarding comradeship and creating an environment that is conducive to learning. We would, however, like to insist that the trainer and their career/confidence is not the focus of this teaching session. The session was designed to improve the understanding and knowledge of overwhelmed medical students with the difficult topic of embryology. Fallaha et al prudently pointed out some of the benefits to the teaching faculties. However, there is a large step in getting senior students to the level where they can confidently teach an intense course for 2 hours and also understand it to sufficient detail to explain it coherently and deal with any queries raised by students.

With regard to our course, the benefits of peer-assisted learning teaching could be applied in the form of further sessions with senior students to ensure good understanding and revision.

We are very grateful for the feedback that we have received from our peers and would also like to extend our thanks to the wider readership that have contacted us directly to implement similar teaching programs at their institutions. We hope that the authors will continue with their enthusiasm to deliver effective teaching programs at their respective institutions. We presented a novel and resource-limited method of teaching embryology to medical students in a way that not only engages them but also reflects the wider pressures that they face from the rest of the course. We will react to the responses from peers to continue to further develop this course and implement changes at when delivering at multiple institutions in the future.

\section{Disclosure}

The authors report no conflicts of interest in this communication.

\section{References}

1. Kazzazi F, Bartlett J. Condensing embryology teaching for medical students: can it be taught in 2 hours? Adv Med Educ Pract. 2017;8:797-806.

2. Carlson BM. Embryology in the medical curriculum. Anat Rec. 2002;269:89-98.

\footnotetext{
Dove Medical Press encourages responsible, free and frank academic debate. The content of the Advances in Medical Education and Practice 'letters to the editor' section does not necessarily represent the views of Dove Medical Press, its officers, agents, employees, related entities or the Advances in Medical Education and Practice editors. While all reasonable steps have been taken to confirm the content of each letter, Dove Medical Press accepts no liability in respect of the content of any letter, nor is it responsible for the content and accuracy of any letter to the editor.
}

\section{Publish your work in this journal}

Advances in Medical Education and Practice is an international, peerreviewed, open access journal that aims to present and publish research on Medical Education covering medical, dental, nursing and allied health care professional education. The journal covers undergraduate education, postgraduate training and continuing medical education including emerging trends and innovative models linking education, research, and health care services. The manuscript management system is completely online and includes a very quick and fair peer-review system. Visit http://www.dovepress.com/testimonials.php to read real quotes from published authors. 